\title{
The Image of Region in Ordinary Language Consciousness of its Residents (on an Example of an Image of Kuzbass)*
}

\section{Образ региона в обыденном языковом сознании его жителей (на примере образа Кузбасса)**}

\section{Olga Kondratyeva}

Dr. in Philology, Associate Professor

\section{Ольга Кондратьева}

доктор филологических наук, профессор

\section{E-mail: kondr25@,rambler.ru orcid.org/0000-0001-9469-3634}

Tatyana Frolova

Student of Institute of Philology,

Foreign Languages and Mediacommunication

\section{Татьяна Фролова}

студентка института филологии, иностранных языков и медиакоммуникаций

\section{E-mail: tatyana_frolova_97@mail.ru}

Kemerovo State University

6, Krasnaya Str., Kemerovo,

Russian, 650000
Кемеровский государственный университет

ул. Красная, 6, г. Кемерово, Россия, 650000

Original manuscript received April 02, 2018

Revised manuscript accepted October 10, 2018

* This work was supported by grant № 18-412-420003 «Kuzbass: Complex Cognitive-discursive Study of the Regional Image» from the Russian Foundation for Basic Research and the government of Kemerovo region, Russian Federation

** Работа выполнена при финансовой поддержке фонда РФФИ и Администрации Кемеровской области, проект № 18-412-420003 «Кузбасс: Комплексное когнитивнодискурсивное исследование образа региона». 


\section{ABSTRACT}

The article solves a topical problem, i.e. it develops the idea about the relevance of the psycholinguistic techniques' usage in the image-building and branding of the regions. In particular it develops the thesis that an initial point of the region successful image's formation is the studying of its image existing in the ordinary language consciousness of its residents and then and in the consciousness of other regions' residents.

Such psycholinguistic researches will give an opportunity to define strong and weak points of the regions in the consciousness of a mass audience. In other words they will let reveal and neutralize risk factors which can negatively affect the region's image and define characteristics which will become a basis for successful region's self-presentation.

In order to demonstrate the efficiency of psycholinguistic techniques' application in the studying of the territory's representation the image of Kuzbass is described. Kuzbass is one of the strategically significant regions of Russia. In the course of the research an experimental psycholinguistic technique was used, including three complementary procedures: 1) a method of subjective definitions; 2) the directed associative experiment; 3) a method of non-complete sentences.

The analysis has shown that the kernel of Kuzbass's image is formed by three semantic groups: "Homeland», "Territory» and "Coal». The named groups are reflected both in the knowledge about the region and in the differently ranked concepts and evaluations which proves their fundamental character. It is also necessary to note that positive evaluations prevail which shows that the doubtless positive attitude of the residents to native region dominates.

The developed coal industry and the positive personal attitude to the region can become meaningful points for an effective Kuzbass brand development. Nevertheless, negative issues are also reflected in the reactions, such as problems in social and recreational areas which should be paid attention to while working on the positive image of Kuzbass.

Key words: Psycholinguistics, ordinary language consciousness, experimental methods, an image of region, Kuzbass.

\section{Вступление}

Настоящее исследование, выполненное на стыке современной имиджелогии, лингвистики и психолингвистики, посвящено описанию особенностей репрезентации образа региона в обыденном языковом сознании носителей русской лигвокультуры.

Образ региона понимается нами как «совокупность ярких, характерных ключевых представлений, устойчивое упрощенное 
обобщение большого числа ассоциаций, связанных с определенной территорией в контексте образа страны» (Федотова, 2014: 112). В настоящий момент вполне очевидно, что образ региона должен целенаправленно конструироваться, поддерживаться и развиваться, создаваемый образ должен быть реалистичным, подчеркивающим специфичность и уникальность территории, вызывающим положительный эмоциональный отклик. Результатом целенаправленно и грамотно созданного образа региона станет его общественно-политическая, культурно-историческая и инвестиционная привлекательность, т.е. его позитивный имидж.

Существующие в данный момент описания образов территорий (стран и регионов) выполняются преимущественно на материале масс-медиа или социальных сетей и блогосфы, то есть объектом исследования до сих пор становились исключительно медиаобразы регионов, в то время как, по нашему мнению, любую деятельность по формированию имиджа региона необходимо начинать с изучения образа региона, реально существующего в обыденном языковом сознании его жителей. Соответственно, использование психолингвистических методик является важным инструментом в данном процессе.

Тем не менее, исследования образов территорий, выполненные с применением экспериментальных методик, позволяющих получить доступ к языковому сознанию, крайне немногочисленны (Киселева, 2009; Колесова, Ганичева, 2016; Тарасов, 2006; Фельде, 2011; Ши Ся, 2008 и др.) и в большей степени касаются изучения образа стран и частей света (России, Китая, Японии, США, Франции, Европы (Киселева, 2009; Кулик, 2012; Петухова, Наумова, 2012; Чесноков, 2003; Ши Ся, 2008), нежели отдельных регионов. Соответственно, проблема изучения образов регионов, существующих в обыденном языковом сознании, остается открытой, а разработка комплексной психолингвистической методики, которая будет использоваться для реконструкции образа региона, является одной из первостепенных задач, первые шаги для решения которой будут намечены в предлагаемом исследовании.

Для демонстрации эффективности применения психолингвистических методик в изучении образа территории описывается образ одного из наиболее значимых в стратегическом отношении регионов России - Кузбасса, к которому в последнее 
The Image of Region in Ordinary Language Consciousness...

время благодаря резким изменениям в социальной и политической сферах обращено особое внимание российской и мировой общественности.

\section{Методика и методы исследования}

В процессе исследования образа Кузбасса, существующего в обыденном языковом сознании жителей Кемеровской области, использовалась экспериментальная психолингвистическая методика, включающая три взаимодополняющие процедуры: 1) метод субъективных дефиниций; 2) направленный ассоциативный эксперимент; 3) метод незавершенных предложений. Перечисленные методы широко используются в психолингвистике в процессе массовых экспериментов с языковым сознанием, их результативность неоднократно подтверждена трудами ученых Московской психолингвистической школы (Караулов, 2000; Уфимцева, 1996; Тарасов, 2006 и др.) а также трудами лингвистов из других регионов России (Голев, 2011; Стернин, 2010; Стексова, 2012 и др.), а также ближнего и дальнего зарубежья (Горошко, 2001; Дмитрюк, 2000; Perea \& Rosa, 2002; Raymond \& Gibbs, 2004 и др.). На наш взгляд, совокупность перечисленных психолингвистических методов позволит определить основные характеристики образа Кузбасса в обыденном языковом сознании его жителей. Метод субъективных дефиниций эксплицирует знания кузбассовцев о регионе, ассоциативный эксперимент позволит выявить свободные неконтролируемые и не всегда осознанные представления о регионе (знание и представление не всегда совпадают в своем объеме, так как «представление - субъективное отражение связей и отношений действительности, и это субъективное отношение эмоционально» (Шахнарович \& Юрьева, 1990: 23), метод незаконченных предложений даст возможность выявить осознанные оценки изучаемого образа региона.

Для верификации эффективности комплексной психолингвистической методики для реконструкции образа изучаемого региона было проведено массовое анкетирование. Респондентами стали сто жителей Кузбасса в возрасте от 15 до 65 лет, имеющие разный уровень образования: от основного общего до высшего. Выбор в качестве информантов людей разного возраста и с разным образованием является для исследования 
Образ региона в обыденном языковом сознании его жителей...

принципиальным, поскольку позволяет реконструировать обобщенный образ родного края, существующий в сознании кузбассовцев.

В анкету было включено три задания, первое основано на методе субъективных дефиниций, второе на ассоциативном эксперименте, третье представляет собой реализацию метода незавершенных предложений.

\section{AHKETA}

1. Кузбасс - это... (информанту необходимо дать определение).

2. Какие ассоциации у Вас вызывает слово «Кузбасс»?

3. Закончите фразы:

1) Я люблю Кузбасс за то, что/ потому что...

2) Я не люблю Кузбасс за то, что/ потому что...

Разноаспектная структура анкеты нацелена на максимально полное выявление характеристик образа Кузбасса в сознании его жителей. Кроме того, полученные результаты будут иметь несомненное прикладное значение - они позволят оценить, как относятся люди к области, в которой живут, насколько они удовлетворены жизнью в регионе.

Настоящая статья дополнительно решает еще одну важную задачу - доказывает целесообразность использования психолингвистических методик в интенсивно развивающихся областях имиджбилдинга и брендинга регионов, в частности, развивает тезис, что исходной точкой формирования успешного имиджа региона является изучение исходного образа региона, существующего в обыденном языковом сознании его жителей, а затем и в сознании жителей других регионов.

Подобные психолингвистические исследования позволят определить сильные и слабые стороны регионов в сознании массовой аудитории, т.е. дадут в итоге возможность выявить и нейтрализовать факторы риска, которые могут негативно сказаться на имидже региона, и определить характеристики, которые могут стать основой для успешного позиционирования региона в глазах россиян и представителей мирового сообщества.

\section{Результаты и дискуссии}

Рассмотрим эффективность психолингвистических методов, используемых для реконструкции образа Кузбасса в языковом 
сознании жителей Кемеровской области, соотнося их с полученными результатами анкетирования.

\section{Метод субъективных дефиниций}

В первом задании анкеты информантам предлагалось продолжить фразу, дав определение слова «Кузбасс». Все ответы были разделены на три семантические группы, ранжированные по степени частотности: 1) «Территория»; 2) «Угольный бассейн»; 3) «Родина». Каждая из этих групп в свою очередь разделена на подгруппы. Следует отметить, что ответы внутри каждой подгруппы делятся на 2 вида: ответы, полностью тождественные названию подгруппы и конкретизированные ответы, позволяющие определить, на чем дополнительно акцентируется внимание респондентов.

1. Семантическая группа «Территория». Респонденты интерпретировали Кузбасс как территорию (область, регион, край, часть Сибири др.), акцентируя внимание на характерных чертах данной территории. Всего было дано 43 ответа подобного типа.

«Территория» - 43: область - 13; регион - 11; край -5 ; место - 4; Сибирь - 4; столица - 2; территория -2; субъект РФ - 1 , индустриально-промышленный район России - 1.

Самое частотное определение Кузбасса как территории связано с конкретизацией местоположения или, иначе говоря, места на карте: область + место на карте - 13: Кемеровская область - 12; область России; регион + место на карте - 5: регион РФ; один из регионов России; регион Сибири; регион в Сибири; регион в сибирском федеральном округе; Сибирь + место на карте - 1: Сибирь, Кемеровская область; территория + место на карте - 2: территория в гранищах Кемеровской области - 1; территория России - 1.

Не менее важным для кемеровчан оказывается тот опыт, который они получили, проживая в Кемеровской области: регион + опыт - 5: регион, полный возможностей; регион, куда я приехала учиться; регион, где проживают крепкие люди, которые могут выдержать любые испытания; регион, в котором я живу; самый лучший регион России, где я родилась, самый богатый и надёжный, мой родной дом; область + опыт - 3: ничем не примечательная область; область, в которой я живу; область, в которой мало хорошо оплачиваемой работы; край + опыт - 1: край, богатый край, но денег мы зарабатьваем мало, детей растить тяжело; 
Сибирь + опыт - 1: Сибирь, место, где я родился; место + опыт 4: - место, где я живу; место, где я родился; место, где я родилась; хорошее место. Полученные дефиниции отражают как положительные черты Кузбасса (регион, полный возможностей; богатый и надежный; самый лучший регион России и др.), так и негативные (область, в которой мало хорошо оплачиваемой работы; денег мы зарабатываем мало, детей растить тяжело).

Следующим по частотности конкретизатором выступает компонент «уголь»: регион + уголь - 3: угольный регион, уголь; угольный регион; регион с большими запасами угля; край + уголь - 2: угольнылй край -2 ; Сибирь + уголь -1 : Сибирь, область промышленная. В Сибири находится самый крупный в мире по местонахождению угля, самый крупный Кузнецкий бассейн; столица + уголь - 1: угольная столица.

Подобные реакции свидетельствуют о том, что в сознании кузбассовцев прочно укоренился образ угольной столицы. Также встречаются ответы, в которых соединены образы угля и местоположения Кузбасса: область + место на карте + родина + профессии - 1: Кемеровская область, моя Родина, край шахтёров и металлургов - мужественных, честных, добрых и порядочных людей; край + история + профессии $-1:$ удивительный край, история которого вызывает интерес и гордость, край шахтёров, химиков, металлургов.

Таким образом, помимо указания на территориальный статус Кузбасса, респонденты при дефинировании акцентировали внимание на таких характеристиках региона, как его расположение (область России, часть Сибири и т.д.), сырьевое богатство (уголь) и развития угольная промышленность, а также эксплицировали свой личный опыт, связанный с проживанием в Кузбассе.

\section{2. Семантическая группа «Угольный бассейн».} Данная группа представлена 22 дефинициями. Десять человек дефинировали слово «Кузбасс» через его этимологию: Кузнецкий угольный бассейн - 8; Кузнеиякий бассейн - 2. И двое - тождественно названию полезного ископаемого, добываемого в регионе: уголь - 2 .

В ответах остальных десяти респондентов также прослеживалась прочная ассоциация Кузбасса с угледобычей и развитой промышленностью: уголь + месторождение -3 : крупнейшее угольное месторождение - 2; угольный бассейн, самое богатое 
месторождение мира; уголь + месторождение + место на карте -2 : одно из самых крупных угольных месторождений мира, расположен на юге Западной Сибири - 2; уголь + промышленность + место на карте - 2: угольная промышленность России; промышленность города, уголь. уголь + место - 1: то место, где есть уголь; уголь + добыча - 1: угледобыча; уголь + промышленность -1 : угольная промышленность.

3. Семантическая группа «Родина». Значительная часть информантов давала определение Кузбасса через понятие родины, соответственно, на первый план при таком подходе выдвигается не официальная трактовка (субъект российской федерации), а эмоционально-личностная. Было зафиксировано 22 дефиниции подобного плана.

«Родина» - 22: Родина - 18; дом - 3; родной город - 1 .

В конкретизированных ответах подчеркивается теплое эмоциональное отношение к родине (любовь, гордость): родина + любовь - 4: любимая родина - 2, самая любимая родина, родина, которую я очень сильно люблю; родина + гордость - 4: моя родина, которой горжусь - 2; наша родина, сила и гордость; наша родина, гордость, Тулеев, а также присутствуют маркеры принадлежности (моя, наша родина): родина + принадлежность -13 : моя родина -5 ; наша родина - 3, моя малая родина - 2, моя любимая родина - 2; родина, моя-моя. Значимым оказалось и восприятие Кузбасса как родного дома: родина + дом - 2: родина, родной дом; моя родина, мой дом.

4. Семантическая группа «Сердце». При дефинировании понятия «Кузбасс» некоторые информанты использовали метафорическую стратегию, называя регион сердцем (чаще всего - угольным), т.е. характеризуя регион как важнейший центр, средоточие российской угледобывающей промышленности:

Сердце - 7: угольное сердие России - 3; угольное сердие страны - 2, сердие Сибири, сердие области.

Помимо выделенных четырех семантических групп в ответах были представлены единичные реакции (6), отражающие отдельные характеристики региона: кузница страны; кузница России; много лесов, полей, угля и хороших людей; широкие просторы; житница Сибири; все. 
Ответ на первое задание анкеты показал, что большинство кемеровчан хорошо знают, что кроется за словом «Кузбасс». Кузбасс - это 1) неофициальное название субъекта Российской Федерации, Кемеровской области, 2) Кузнецкий угольный бассейн, одно из самых крупных угольных месторождений мира, расположенное на юге Западной Сибири, в основном на территории Кемеровской области). Оба значения актуализированы в дефинициях, предложенных респондентами, кроме того, участники эксперимента продемонстрировали теплое личностное отношение к региону, что выражается в высокой частотности значения «Родина».

Развитая сфера углепромышленности и позитивно-личностное отношение к региону могу стать значимыми точками для развития эффективного бренда Кузбасса (богатый сырьевой регион и регион, который любят его жители). Тем не менее, в дефинициях нашли отражение отдельные негативные моменты, такие, как проблемы в социальной сфере и сфере образования, на которые следует обратить внимание при дальнейшей работе над позитивным имиджем Кузбасса.

\section{Метод ассоциативного эксперимента}

Второй вопрос анкеты (Какие ассоциации у Вас вызыввает слово «Кузбасс»?), был нацелен на выявление у кузбассовцев стойких ассоциаций, связанных с регионом. Под ассоциацией понимают «возникающую в опыте индивида закономерную связь между двумя содержаниями сознания (ощущениями, представлениями, мыслями, чувствами и т. п.), которая выражается в том, что появление в сознании одного содержания влечет за собой и появление другого» (Мещеряков \& Зинченко, 2003: 17).

При проведении ассоциативного эксперимента респонденты не были ограничены количеством требуемых ассоциаций. Поэтому у некоторых респондентов была зафиксирована лишь одна ассоциация, у других - от двух до шести. Всего было получено 255 ассоциаций.

Полученные реакции были разделены на несколько семантических групп и ранжированы по степени их частотности: 1) «Угольная промышленность», 2) «Родина», 3) «Территория», 3) «Личная оценка», 4) «Природа, климат», 5) «Политика, история», 5) «Социальная сфера», 7) «Люди», 8) «Места, учреждения», 9) «Туристические объекты». 
Самой частотной среди ассоциаций оказалась семантическая группа «Угольная промышленность» - 106: Уголь - 68; шахтеры - 20; шахта - 8; угледобыча - 6; добытчики угля - 3; «Шахтерская слава» - 1. Как видно из перечисленных выше реакций, в данном блоке анкеты по сравнению с предыдущим акценты несколько сместились и образ угля и шахтеров, хранящийся в сознании кузбассовцев, вышел на первое место.

Вторую позицию занимает семантическая группа «Родина», представленная 18 реакциями: Родина - 9, малая родина - 7, родной дом - 2. Показательно, что количество реакций в данном блок практически такое же, как и в предыдущем (18 и 20 соответственно), следовательно, можно говорить об устойчивости ассоциаций Кузбасс - родина.

В семантической группе «Территория» наиболее частотными стали следующие ответы: Сибирь - 11; Кемерово - 8. Эти результаты свидетельствуют о том, что в сознании кузбассовцев наш регион прочно связан с Сибирью, т.е. воспринимается как ее часть и со столицей области.

Наблюдение о том, что кузбассовцы гордятся своей областью, подтверждается появлением группы ассоциаций, в которую входят эмоционально окрашенные слова, отражающие непосредственные переживания респондентов. Семантическая группа «Личная оценка» представлена тридцатью ассоциациями, большая часть из которых положительная.

Семантическая группа «Личная оценка»-30. Положительная оценка - 24: Сила - 6; гордость - 6; богатство - 4; любимый - 4; превосходство - 2; красноречивость - 2. Отрицательная оценка - 6: Никаких - 2; ужас - 1; серость - 1; суровость - 1; область, которой может и не быть - 1 .

Важное место в сознании кузбассовцев занимают ассоциации, связанные с природными и климатическими характеристиками региона: Семантическая группа «Природа, климат» - 26: природные красоть - 4; Томь - 4; природа - 3; снег - 3; зима - 3; лес - 2; поля - 2; грязь -2; пыль - 1; горы - 1; медведи - 1 .

Семантические группы «Политика, история», «Социальная сфера» и «Люди» актуализируют особенности жизни в регионе. Заслуживает внимания полярность ответов в данных группах. Во главу угла встает образ действующего на момент проведения 
анкетирования губернатора (cp. в предыдущем задании он упоминался единожды) и связанные с ним социальные гарантии. Образ главы региона также можно использовать в качестве оплота при формировании бренда и имиджа области: «Политика, история» - 26: Тулеев - 16; губернатор - 8; история - 1; памятные места - 1. «Социальная сфера» - 11: кузбасский социализм - 4; социальные гарантии для жителей региона - 4, коррупция - 1; безработица - 1; нищета - 1. «Люди» - 11: Люди - 5; труженики - 5; пенсионеры - 1;

Наименее частотными оказались семантические группы «Места, учреждения» - 5 и "Туристические объекты» - 3: Волейбольный клуб - 2; набережная - 1; КемГУ - 1; большие буквы на горе - 1 и Шерегеш - 2; Танай - 1. Последнее несколько неожиданно, так как Шерегеш уверенно входит в тройку лучших горнолыжных курортов России. Тем не менее, в сознании кузбассовцев этот факт пока не нашел отражения, соответственно, необходимо усилить деятельность по позиционированию туристических зон Кузбасса, при грамотной работе они могут стать основой для конструирования успешного бренда региона.

Проанализировав результаты, полученные при выполнении респондентами второго задания анкеты, можно заключить, что в сознании жителей Кемеровской области прочно укоренились такие ассоциации, связанные с Кузбассом, как уголь, шахты, природа, губернатор. Также следует отметить, что большинство ассоциаций оценочны и эмоционально окрашены, при этом значительная их часть позитивна или нейтральна.

\section{Метод незавершенных предложений}

Ассоциации, на выявление которых было ориентировано второе задание анкеты, имеют автоматическую природу, характеризуются слабой способностью человека управлять ими, поэтому третье задание анкеты ориентировано на выявление осмысленного, сознательного отношения к региону, на экспликацию эмоциональнооценочной составляющей его образа. Информантам необходимо было продолжить два полярных предложения: 1) Я люблю Кузбасс за то, что/ потому что... и 2) Я не люблю Кузбасс за то, что / потому что...

В количественном отношении ответы на тот и другой вопрос примерно одинаковы, однако в содержательном наполнении они 
существенно разнятся. Так, на первом месте среди причин любви к Кузбассу в результате ранжирования по частотности оказались ответы из семантической группы «Родина», в этой группе оказалось 56 ответов: Я здесь родил(а)ся - 18; родина - 17; я тут (здесь) жсиву - 14; я тут вырос(ла) - 4; родной дом - 3.

Среди причин нелюбви к Кузбассу в начале списка (38 реакций) оказалась семантическая группа «Социальная сфера»: Маленькие (низкие) зарплать - 14; коррупцуия - 4; негде работать - 4; высокие цень - 2; мало хорошо оплачиваемой работы - 2; мало (нет) работы для молодежи - 2; безработиц̧а - 1; нехватка рабочих рук - 1; маленькие пенсии - 1; наше руководство часто бросает пьль в глаза - 1; здесь не проводят гомосексуальные митинги - 1; отсутствие некоторых видов спорта и спонсорской поддержки - 1; низкая занятость населения - 1; нет мест отведенных для выгула собак - 1; благосостояние людей падает - 1; много происшествий и нарушений закона -1 .

Исходя из результатов, можно сказать, что кузбассовцев серьезно беспокоит ситуация, связанная с трудоустройством и оплатой труда, эта проблема в нашей области является одной из наиболее острых и требует оперативного решения.

Также в ответах на вопрос о причинах нелюбви к Кузбассу появляются новые семантические группы, ранее не встречавшиеся «Образование, развитие», «Здоровье, медицина» и «Досуг». По мнению жителей Кузбасса, в нашей области эти сферы недостаточно развиты или не развиты вообще: «Образование, развитие» - 13: Недостаточно выссиих (и средних) учебных заведений - 4; проблемь в развитии - 3; ограниченные перспективы - 2; нет нормального образования - 1; мало городов-миллионников - 1; проблемь в экономике - 1; меня заставляют переводить про уголь - 1 . «Здоровье, медицина» - 3: Заболевания - 2; плохое лечение - 1 . «Досуг» - 3: Мало мест для развлечений - 1; мало красивых мест для прогулок - 1. плохой туризм - 1 .

Обращает на себя внимание факт, что семантическая группа «Угольная промышленность», представленная шестнадцатью реакциями, примерно одинаково отражена в качестве причины как любви, так и нелюбви к Кузбассу: Я люблю Кузбасс, потому чтоо (7): Уголь - 5; один из сильнейших промышленных регионов России - 1; родина угля и нефти - 1. Я не люблю Кузбасс, потому 
что (9): Мало (нет) нефти -3; много угля - 3; разрезы - 2; не развита промылиленность - 1. Это свидетельствует о том, что в данном направлении требуется более тщательная работа, поскольку эта сфера перспективна и очень важно потенциально успешный для формирования бренда региона компонент не трансформировать в негативную составляющую имиджа Кузбасса.

Говоря об эмотивном аспекте изучения образа Кузбасса в сознании его жителей, можно отметить, что сильными факторами являются темы родины и угледобычи, слабыми - трудоустройство, образование, здравоохранение, благоустройство и досуг.

\section{Выводы}

В процессе исследования была эффективно апробирована комплексная психолингвистическая методика, включающая взаимодополняющие процедуры, совокупность которых позволила эксплицировать знания кузбассовцев о регионе (метод субъективных дефиниций), определить свободные неконтролируемые и не всегда осознанные представления о регионе (ассоциативный эксперимент) и выявить осознанные оценки изучаемого региона (метод незаконченных предложений), что в итоге позволило реконструировать объемный образ Кузбасса в обыденном языковом сознании его жителей.

Анализ показал, что ядро образа Кузбасса образуют три семантические группы: «Родина», «Территория» и «Угольный бассейн / Уголь». Названные группы отражены как в знаниях о регионе, так в представлениях и оценках (правда, по-разному ранжированы в них), что убедительно свидетельствует об их доминирующем характере. Следует также отметить, что слабо контролируемые ассоциации на слово Кузбасс и осознанные, целенаправленные ответы на вопрос Почему я люблю / не люблю Кузбасс совпали в коннотативном аспекте, доминирующими являются позитивные оценки, что демонстрирует несомненное позитивное отношение жителей к родному краю.

Проведенное исследование продемонстрировало эффективность использования комплекса психолингвистических методов для реконструкции образа родного региона, позволило выявить сильные и слабые характеристики данного образа, что даст возможность начать работу по корректировке негативных моментов 
The Image of Region in Ordinary Language Consciousness...

и эффективно использовать сильные стороны образа региона при создании позитивного имиджа Кузбасса.

Перспективой исследования является сопоставление «внутреннего образа» Кузбасса с его «внешним образом», т.е. образом, существующим в обыденном языковом сознании жителей других регионов и представителей других стран. Подобное смещение исследовательского акцента позволит получить комплексное представление об образе региона для дальнейшей работы над созданием успешного имиджа Кемеровской области.

\section{Литература}

Голев, Н.Д. Мотивационно-ассоциативный словарь русского языка: теоретические основания и лексикографическая концепция. Вестник Томского государственного университета. Сер. Филология. № 3(15). 2011. С. 17-30.

Горошко, Е.И. Интегративная модель свободного ассоциативного эксперимента. Харьков : Ра-Каравелла, 2001. 320 с.

Дмитрюк, Н.В. Формы существования и функционирования языкового сознания в негомогенной лингвокультурной среде : дис. ... д-ра филол. наук. Москва, 2000. 445 c.

Караулов, Ю.Н. Показатели национального менталитета в ассоциативновербальной сети. Языковое сознание и образ мира. Москва : ИЯ РАН, 2000. C. 191-206.

Киселева, Е.А. Опыт экспериментального психолингвистического исследования образов России и Японии в обыденном сознании студентов Новосибирского государственного университета. Вестник Новосибирского государственного университета. Сер. Лингвистика и межкультурная коммуникация. 2009. Том 7. Вып. 2. С. 103-115.

Колесова, И.Е., Ганичева, С.А. Образ Вологды в языковой картине мира студентов и школьников. Актуальные проблемы обучения русскому языку XII : Материалы международной конференции / Ed. Anastasia Sokolova. Masarykova univerzita Pedagogická fakulta. Brno : Masarykova univerzita, 2016. C. $179-184$.

Кулик, Д.П. Образ Франции в языковом сознании сибирских студентов (на материале психолингвистического эксперимента). Молодёжь $u$ наука : Сборник материалов VIII Всероссийской научно-технической конференции студентов, аспирантов и молодых учёных, посвященной 155 -летию со дня рождения К.Э. Циолковского [Электронный ресурс]. Красноярск : Сибирский федеральный ун-т, 2012. Режим доступа: http://conf. sfu-kras.ru/sites/mn2012/section28.html

Мещеряков, Б.Г., Зинченко, В.П. Большой психологический словарь. Москва : Прайм-Еврознак, 2003. 672 с.

Петухова, В., Наумова, Н.Г. Объективация концепта «Америка» в языковом сознании современной молодежи. Проблемь языковой картинь мира в синхронии и диахронии : сборник материалов Всероссийской конференции молодых ученых. Нижний Новгород : НГПУ, 2014. С. 18-24. 
Образ региона в обыденном языковом сознании его жителей...

Стексова, Т.И. Образ политика в СМИ и обыденном языковом сознании. Вестник Новосибирского государственного университета. Сер. История, филология. 2012. Т. 11. Вып. 6. С. 78-83.

Стернин, И.А. Языковое сознание жителей Воронежа. Воронеж : Истоки, 2010. $250 \mathrm{c}$.

Тарасов, Е.Ф. Образ России: методология исследования. Bопросы психолингвистики. 2006. № 4. С. 69-73.

Уфимцева, Н.В. Русские: опыт еще одного самосознания. Этнокультурная специфика языкового сознания: сборник статей / отв. ред. Н.В. Уфимцева. Москва : ИЯ РАН. 1996. С. 144-162.

Федотова, А.В. Формирование образа Мурманской области в полиграфической рекламе региона. Общество. Среда. Развитие (Terra Huтапа). 2014. № 2(31). С. 112-116.

Фельде, О.В. Свои и чужие в языковом сознании сибиряков. Вестник Томского государственного университета. Сер. Филология. № 3(15). 2011. С. 59-64.

Чесноков, И.И. Концепт ЕВРОПА в языковом сознании российских студентов. Вестник Волгоградского государственного университета. Сер. 2. Языкознание. 2003. № 3. С. 69-72.

Шахнарович, А.М., Юрьева, Н.М. Психолингвистический анализ семантики и грамматики. Москва : Наука, 1990. 168 с.

Ши, Ся. Концепт КИТАЙ в русском обыденном языковом сознании : дисс. ... канд. филол. наук. Москва, 2008. 209 с.

Perea, M, \& Rosa, E. (2002). The effects of assotiative and semantic priming in the lexical decision task. Psychological Research, 66(3), 180-194. DOI: 10.1007/ s00426-002-0086-5

Gibbs, R.W. (2004) Psycholinguistic Experiments and Linguistic-Pragmatics. In Noveck I.A., Sperber D. (Eds.), Experimental Pragmatics. Palgrave Studies in Pragmatics, Language and Cognition (pp. 50-71). Palgrave Macmillan, London. DOI https://doi.org/10.1057/9780230524125_3

\section{References}

Golev, N.D. (2011). Motivacionno-associativnyj slovar russkogo yazyka: teoreticheskie osnovaniya i leksikograficheskaya koncepciya [Motivational and associative dictionary of Russian: theoretical bases and lexicographic concept]. Vestnik Tomskogo gosudarstvennogo universiteta - Filologiya Tomsk State University Journal of Philology, 3(15), 7-30 [in Russian].

Goroshko, E.I. (2001). Integrativnaya model svobodnogo associativnogo eksperimenta [Integral model of free associative experiment]. Harkov : Ra-Karavella [in Russian].

Dmitryuk, N.V. (2000). Formy sushestvovaniya i funkcionirovaniya yazykovogo soznaniya $\mathrm{V}$ negomogennoj lingvokulturnoj srede [Forms of existence and functioning of language consciousness in not homogeneous linguocultural to environment]. Philology Dr. Diss. Moscow [in Russian].

Karaulov, Yu.N. (2000). Pokazateli nacionalnogo mentaliteta v associativno-verbalnoj seti [Parameters of national mentality in an associative-verbal network], Yazykovoe soznanie $i$ obraz mira - Language consciousness and image of the world (pp. 191-206). Moscow : IYa RAN [in Russian].

Kiseleva, E.A. (2009). Opyt eksperimentalnogo psiholingvisticheskogo issledovaniya obrazov Rossii i Yaponii $\mathrm{v}$ obydennom soznanii studentov Novosibirskogo 
The Image of Region in Ordinary Language Consciousness...

gosudarstvennogo universiteta [Experience experimental psycholinguistic researches of images of Russia and Japan in ordinary consciousness of students of Novosibirsk state university]. Vestnik Novosibirskogo gosudarstvennogo universiteta. Lingvistika i mezhkulturnaya kommunikaciya - Novosibirsk State University Journal of Linguistics and Intercultural Communication, 7(2), 103115 [in Russian].

Kolesova, I.E., \& Ganicheva, S.A. (2016). Obraz Vologdy v yazykovoj kartine mira studentov i shkolnikov [Image of Vologda in a language picture of the world of students and students]. Proceedings from International Scientific Conference '17: Mezhdunarodnaya nauchnaya konferenciya "Aktualnye problemy obucheniya russkomu yazyku XII» - The international scientific conference "Actual problems of teaching Russian language XII» (pp. 179-184). Brno [in Russian].

Kulik, D.P. (2012). Obraz Francii v yazykovom soznanii sibirskih studentov (na materiale psiholingvisticheskogo eksperimenta) [The image of France in the linguistic consciousness of Siberian students (based on the psycholinguistic experiment)]. Proceedings from International Scientific Conference '12: VIII Vserossijskaya nauchno-tehnicheskaya konferenciya studentov, aspirantov $i$ molodyh uchyonyh, posvyashennaya 155-letiyu so dnya rozhdeniya K.E. Ciolkovskogo «Molodyozh $i$ nauka» - VIII All-Russia scientific and technical conference of students, post-graduate students and the young scientists, devoted to the 155 anniversary from the date of K.E. Tsiolkovskys birth "Youth and science». Krasnoyarsk : Sibirskij federalnyj un-t. URL : http://conf.sfu-kras. $\mathrm{ru} / \mathrm{sites} / \mathrm{mn} 2012 / \mathrm{section} 28 . h t m l$ [in Russian].

Mesheryakov, B.G., \& Zinchenko, V.P. (2003). Bolshoj psihologicheskij slovar [The big psychological dictionary]. Moscow : Prajm-Evroznak [in Russian].

Petuhova, V., \& Naumova, N.G. (2014). Obektivaciya koncepta «Amerika» v yazykovom soznanii sovremennoj molodezhi [Objectivization of the concept of «America» in the linguistic consciousness of modern youth]. Proceedings from of the All-Russian Conference '14 : Vserossijskaya konferenciya molodyh uchenyh "Problemy yazykovoj kartiny mira v sinhronii i diahronii» - All-Russian Conference of Young Scientists "Problems of the language picture of the world in synchrony and diachrony». (pp. 18-24). Nizhnij Novgorod : NGPU. [in Russian].

Steksova, T.I. (2012). Obraz politika v SMI i obydennom yazykovom soznanii [Image of the politician in mass-media and ordinary language consciousness]. Vestnik Novosibirskogo gosudarstvennogo universiteta. Istoriya, filologiya - Novosibirsk State University Journal of History, Philology, 11(6), 78-83 [in Russian].

Sternin, I.A. (2010). Yazykovoe soznanie zhitelej Voronezha [Language consciousness of residents of Voronezh]. Voronezh : Istoki [in Russian].

Tarasov, E.F. (2006). Obraz Rossii: metodologiya issledovaniya [Image of Russia: methodology of research]. Voprosy psiholingvistiki - Journal of psycholinguistics, 4, 69-73 [in Russian].

Ufimceva, N.V. (1996). Russkie: opyt eshe odnogo samosoznaniya [Russian: experience of one more consciousness], Etnokulturnaya specifika yazykovogo soznaniya [Ethnocultural specific character of language consciousness], (pp. 144-162). Moscow : IYa RAN [in Russian].

Fedotova, A.V. (2014). Formirovanie obraza Murmanskoi oblasti v poligraficheskoi reklame regiona [Formation of the image of the Murmansk region in the polygraphic advertisement of the region]. Obshchestvo. Sreda. Razvitie (Terra Humana) - Society. Wednesday. Development (Terra Humana), 2(31), 112-116 [in Russian]. 
Образ региона в обыденном языковом сознании его жителей...

Felde, O.V. (2011). Svoi i chuzhie v yazykovom soznanii sibiryakov [Its and strangers in the language consciousness of Siberians]. Vestnik Tomskogo gosudarstvennogo universiteta. Filologiya - Tomsk State University Journal of Philology, 3(15), 59-64 [in Russian].

Chesnokov, I.I. (2003). Koncept EVROPA v yazykovom soznanii rossijskih studentov [Concept the Europe in language consciousness of the Russian students]. Vestnik Volgogradskogo gosudarstvennogo universiteta. Yazykoznanie - Volgograd State University Journal of Linguistics, 3, 69-72 [in Russian].

Shahnarovich, A.M., \& Yureva, N.M. (1990). Psiholingvisticheskij analiz semantiki $i$ grammatiki [Psycholinguistic analysis of semantics and grammar]. Moscow : Nauka [in Russian].

Shi, Sya. (2008). Koncept KITAJ v russkom obydennom yazykovom soznanii [Concept China in Russian ordinary language consciousness]. Philology Ph.D. Diss. Moscow [in Russian].

Perea, M, \& Rosa, E. (2002). The effects of assotiative and semantic priming in the lexical decision task. Psychological Research, 66(3), 180-194. DOI: 10.1007/ s00426-002-0086-5

Gibbs, R.W. (2004) Psycholinguistic Experiments and Linguistic-Pragmatics. In Noveck I.A., Sperber D. (Eds.), Experimental Pragmatics. Palgrave Studies in Pragmatics, Language and Cognition (pp. 50-71). Palgrave Macmillan, London. DOI https://doi.org/10.1057/9780230524125_3

\section{АННОТАЦИЯ}

Статья решает актуальную задачу - развивает идею о целесообразности использования психолингвистических методик в имиджбилдинге и брендинге регионов, в частности, развивает тезис, что исходной точкой формирования успешного имиджа региона является изучение его образа, существующего в обыденном языковом сознании его жителей, а затем и в сознании жителей других регионов.

Подобные психолингвистические исследования позволят определить сильные и слабые стороны регионов в сознании массовой аудитории, т.е. дадут возможность выявить и нейтрализовать факторы риска, которые могут негативно сказаться на имидже региона, и определить характеристики, которые станут основой для успешного позиционирования региона.

Для демонстрации эффективности применения психолингвистических методик в изучении образа территории описывается образ одного из значимых в стратегическом отношении регионов России - Кузбасса. В процессе исследования использовалась экспериментальная психолингвистическая методика, включающая три взаимодополняющие процедуры: 1) метод субъективных дефиниций; 2) направленный ассоциативный эксперимент; 3) метод незавершенных предложений.

Анализ показал, что ядро образа Кузбасса образуют три семантические группы: "Родина», "Территория» и "Уголь». Названные 
группы отражены как в знаниях о регионе, так в представлениях и оценках (правда, по-разному ранжированы в них), что свидетельствует об их основополагающем характере. Следует также отметить, доминирующими являются позитивные оценки Кузбасса, что демонстрирует несомненное позитивное отношение жителей $к$ родному краю.

Развитая сфера углепромышленности и позитивно-личностное отношение к региону могу стать значимыми точками для развития эфрфективного бренда Кузбасса. Тем не менее, в реакциях отражены и негативные моменты, такие, как проблемы в социальной сфере и сфрере досуга и отдыха, на которые следует обратить внимание при дальнейщей работе над позитивным имиджем Кузбасса.

Ключевые слова: психолингвистика, обыденное языковое сознание, экспериментальные методы, образ региона, Кузбасс.

\section{Кондратьєва Ольга, Фролова Тетяна. Образ регіону в повсякденній мовній свідомості його жителів (на прикладі образу Кузбаса)}

\section{АНОТАЦІЯ}

Стаття вирішує актуальне завдання - розвиває ідею про доцільність використання психолінгвістичних методик в іміджбілдинзі брендінгу регіонів, зокрема, поширює тезу, що вихідною точкою формування успішного іміджу регіону є вивчення його образу, що існує в повсякденній мовній свідомості його жителів, а також $і$ в свідомості жителів інших регіонів. Подібні психолінгвістичні дослідження дозволять визначити сильні й слабкі сторони регіонів у свідомості масової аудиторії, тобто дадуть можливість виявити й нейтралізувати фактори ризику, які можуть негативно позначитися на іміджі регіону, i визначити характеристики, які стануть основою для успішного позиціонування регіону.

Для демонстрації ефективності застосування психолінгвістичних методик у вивченні образу території описується образ одного із значущих в стратегічному відношенні регіонів Росії - Кузбасу. В процесі дослідження використовувалася експериментальна психолінгвістична методика, що включає три взаємодоповнюючі процедури: 1) метод суб'єктивних дефініцій; 2) спрямований асоціативний експеримент; 3) метод незавершених речень.

Аналіз показав, що ядро образу Кузбасу утворюють три семантичні групи: "Батьківщина», "Територія» $і$ "Вугілля». Названі групи відображені як в знаннях про регіон, так $і$ в уявленнях та оцінках (щоправда, по-різному ранжовані в них), що свідчить про їх основоположний характер. Домінуючими є позитивні оцінки Кузбасу, 
Образ региона в обыденном языковом сознании его жителей...

що демонструє безсумнівну позитивне ставлення жителів до рідного краю.

Розвинена Вуглепромислова сфера й позитивно-особистісне ставлення до регіону можуть стати значущими точками відліку для розвитку ефективного бренду Кузбасу. Проте, в реакціях відображені й негативні моменти, такі, як проблеми в соціальній сфрері та сфрері дозвілля й відпочинку, на які слід звернути увагу при подальшій роботі над позитивним іміджем Кузбасу.

Ключові слова: психолінгвістика, повсякденна мовна свідомість, експериментальні методи, образ регіону, Кузбас. 